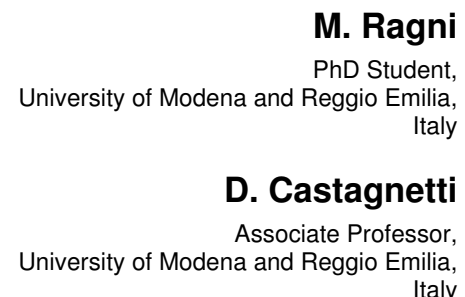

Italy

A.Spaggiari

Assistant Professor University of Modena and Reggio Emilia,

F. Muccini

Student

University of Modena and Reggio Emilia,

Italy

\section{E. Dragoni}

Full Professor, University of Modena and Reggio Emilia,

Italy

M. Milelli

Tellure Rôta S.p.A, Via Quattro Passi 15, Formigine (MO),

Italy

S. Girlando

Tellure Rôta S.p.A, Via Quattro Passi 15, Formigine (MO),

P. Borghi

Tellure Rôta S.p.A Via Quattro Passi 15, Formigine (MO),

\section{Shear Strength Characterization of Metal-Elastomer Bonded Joints}

The shear strength characterization of bonded joints involving adherends with a remarkably different stiffness has a peculiar interest in industrial applications. This work proposes and investigates three innovative specimens (an axisymmetric annular, a tensile and a torsional one) purposely developed to manage dissimilar adherends bonded with adhesive in thin film. A Thick Adherend Shear Test specimen between rigid adherends is used for the assessment of the adhesive by itself. The work focuses on metal-elastomeric polyurethane bonded joints with a solventbased adhesive. All the tests are performed through an axial dynamometer, using a purposely developed fixture to convert the tensile load in a torque for the torsional specimen. The tensile and the torsional specimens provide the most reliable shear strength characterization.

Keywords: bonded joints; dissimilar adherends; thin film adhesive; elastomer; specimen.

\section{INTRODUCTION}

Bonded joints between dissimilar adherends, in particular metal and elastomer with a thin adhesive layer in-between, can be found in many industrial applications. For example, pallet truck wheels feature a coating of a solid elastomeric layer bonded to the metal body (cast iron or steel). In the offshore oil industry, rubber-metal bonded composites are used to protect the structure from seawater. This paper deals with the experimental characterization of the shear strength of this type of bonded joints.

A few works can be traced in the literature about metal-elastomer joints. Stevenson [1], Hamade [2] and Liechti et al. [3] evaluated the joint strength for metalrubber adherends in corrosive environment. Othman [4] studied the drawbacks of peel test for the assessment of metal-rubber joints. The ASTM D429 standard [5]-[6] suggests some specimens for testing metal-elastomer joints. Many works in the literature deal with the development of bonded specimens for the characterization of thin adhesive films between rigid

Received: September 2016, Accepted: October 2016

Correspondence to: Dr Marina Ragni

Department of Science and Methods for Engineering,

Via G. Amendola 2 Reggio Emilia, Italy.

E mail: marina.ragni@unimore.it

doi:10.5937/fmet1703360R

(C) Faculty of Mechanical Engineering, Belgrade. All rights reserved adherends [6]-[10].

This work aims to develop and experimentally assess innovative specimens for the shear strength characterization of bonded joints involving adherends with a remarkably different stiffness and with adhesive in thin film. Four different joint specimens are proposed and investigated. First, a Thick Adherend Shear Test (TAST) [11] specimen to assess the shear strength of the adhesive between rigid adherends. Second, an axisymmetric specimen featuring an annular elastomeric ring which is bonded, on the inner diameter, to a rigid hollow shaft: an annular fixture applies an axial load to the elastomeric ring. Third, a tensile specimen, resembling the TAST specimen [11]. This specimen features a sandwich metal-elastomer-metal configuration, bonded one each other, and undergoes shear load. Fourth, a torsional specimen, where an elastomeric annular ring is bonded internally and externally to a rigid shaft and a hub, respectively: a torque is applied between the shaft and the hub.

Three are the steps of the work. The first step describes the conceptual design of the specimens. The second step presents the design and the development of the proposed specimens. The third step reports the experimental assessment of the most promising specimens, which involves a thermoplastic solventbased adhesive. The results highlight that the TAST-like specimen and the torsional specimen provide the 
simplest and reliable evaluation of the shear strength between adherends with a remarkably different stiffness. In addition, these specimens can be fruitfully applied to a wide range of dissimilar adherends and adhesives.

\section{MATERIAL AND METHODS}

\subsection{Conceptual design}

Table 1 presents the client needs identified for the metal-elastomer bonded specimens and the corresponding weight.

\section{Table 1: Client needs}

\begin{tabular}{|l|l|}
\hline Client needs & Weight \\
\hline Simple manufacturing & 5 \\
\hline Uniform shear stress field & 5 \\
\hline $\begin{array}{l}\text { Gives information for bonded } \\
\text { joints improvement }\end{array}$ & 5 \\
\hline $\begin{array}{l}\text { Applicable to an axial } \\
\text { dynamometer }\end{array}$ & 4 \\
\hline Low-cost & 3 \\
\hline
\end{tabular}

By keeping into account the above client needs, this section proposes and qualitatively compares four specimen configurations for the shear stress characterization of a thermoplastic solvent-based adhesive, which is peculiar for bonding of steel or cast iron to elastomeric polyurethane.

Figure 1 shows a TAST specimen [7], with metallic adherends. This specimen gives the shear strength of the adhesive by itself, disregarding the effect of a stiffness mismatch between the adherends. Due to the experimental constraints, the specimen dimensions (Figure 1a) slightly differ from those prescribed by the standard [7]. An axial load is applied to the specimen through fork pin fixtures on each ends, so as to obtain a pure shear loading on the bonded joint (Figure 1b).

Figure $2 \mathrm{a}$ shows an axisymmetric annular specimen, consisting of a hollow shaft with an annular elastomeric ring bonded outside: the annular ring is casted onto the hollow shaft, where the adhesive is preliminary applied. The dimensions of the specimen (Figure 2a) were mainly chosen considering the manufacturing constraints.

Figure $2 \mathrm{~b}$ shows a detail of the fixture used in the experimental test to support the specimen. In order to obtain a more uniform stress distribution on the specimen, the test is performed by enclosing the annular ring between a support pipe P1 and a cover plate P2 (Figure 2b).

An axial load is applied to the hollow shaft ( $S$ in Figure 2b), up to complete failure of the bonded joint.

In order to evaluate the shear stress distribution, we implemented an axisymmetric finite element (FE) model of the specimen, loaded against a rigid annular ring (Figure 3a). The FE analysis shows a remarkable not-uniform shear stress distribution along the bondline. As expected, a noticeable shear stress concentration occurs in the lower boundary, where the pipe P1 pushes against the elastomeric ring. In addition, the elastomeric ring bends upward thus giving in the same region a remarkable peel stress concentration. On the whole, due to this peculiar behaviour, the specimen can be used only for qualitatively comparing different bonding treatments, without obtaining a quantitative characterization of the shear strength.

Figure $4 \mathrm{a}$ shows the sketch of the TAST-like specimen here proposed, consisting in a sandwich obtained by bonding an inner elastomeric layer (D) to a couple of metal adherends (C). These three layers are bonded each other. The plates $(A)$ act as connecting elements between the top and bottom cross-head of the testing machine, and the sandwich specimen. The plates $B$ join the plates $A$ to the sandwich specimen. By applying an axial load to the TAST-like specimen (in the vertical direction), a shear stress distribution arises in the adhesive layer: the stiffer the central sandwich, the more uniform the shear stress distribution on the adhesive.

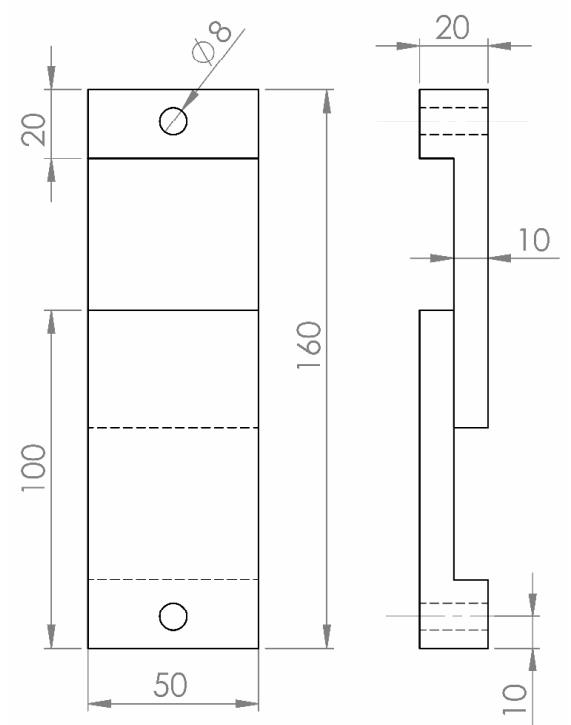

(a)

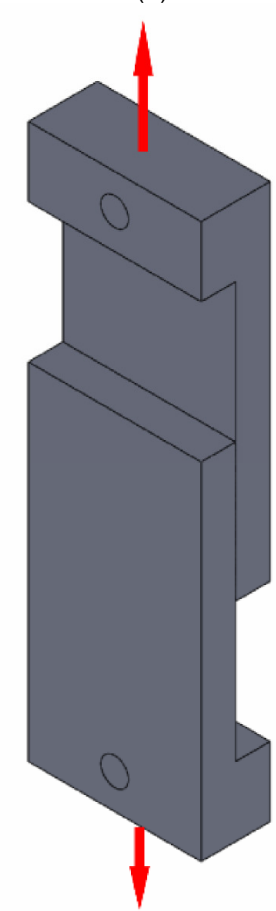

(b)

Figure 1 - TAST specimen: (a) technical drawing, (b) 3D model

A plane stress FE analysis (Figure 5a-b) confirms that, for a metal-elastomer sandwich, large displa- 
cements and large strains occur on the central elastomeric layer (D), for a given axial displacement applied to the specimen. Therefore, a non-uniform shear stress (Figure 5a) and peel stress (Figure 5b) distribution originates on both adhesive layers, with peak stresses on the boundaries: the lower the ratio between the thickness and the length for the elastomeric adherend, the lower the peak stresses in the adhesive. Despite this drawback, the TAST-like specimen is easy to manufacture and allows performing comparative evaluation between, for example, different pairs of adherends or adhesives, simply by using a tensile testing machine. The specimen dimensions (Figure 4a) mainly come from the production constraints, in particular, with regard to the available mold thickness for polyurethane casting.

Figure 6 shows the sketch of the torsional specimen, composed by an elastomeric annular ring bonded on the inner and outer diameter to a central rigid shaft and an outer rigid hub, respectively. By applying a torque to the specimen, a uniform shear stress originates both on the outer and inner adhesive layer: we highlight that the shear stress field is constant both in the circumferential and in the axial direction. The specimen dimensions, specifically the axial thickness of the elastomeric annular ring $(10 \mathrm{~mm})$ and its inner diameter $(20 \mathrm{~mm})$ are the best tradeoff between a failure torque that can be applied by our testing machine and the production constraints.

Table 2 presents the scoring matrix for a quantitative evaluation of the proposed specimens. The specimens are evaluated according to the client needs and their importance, as described in Table 1. The results show that the TAST-like and the torsional specimens are the most promising solutions.

\subsection{Preliminary tests}

Despite the lower scoring from the evaluation performed in Table 2, some preliminary tests were performed on the TAST and axisymmetric annular specimen. Figure 7 shows a test on the axisymmetric annular specimen. These tests exhibited many drawbacks for these type of specimens. The TAST specimens showed a poor polymerization since the adhesive formulation is specific for a metallic adherend combined with an elastomeric one, but it is not suitable in case both adherends are metallic.

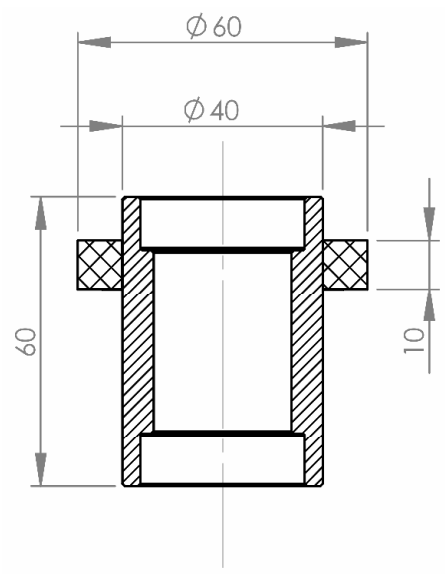

(a)

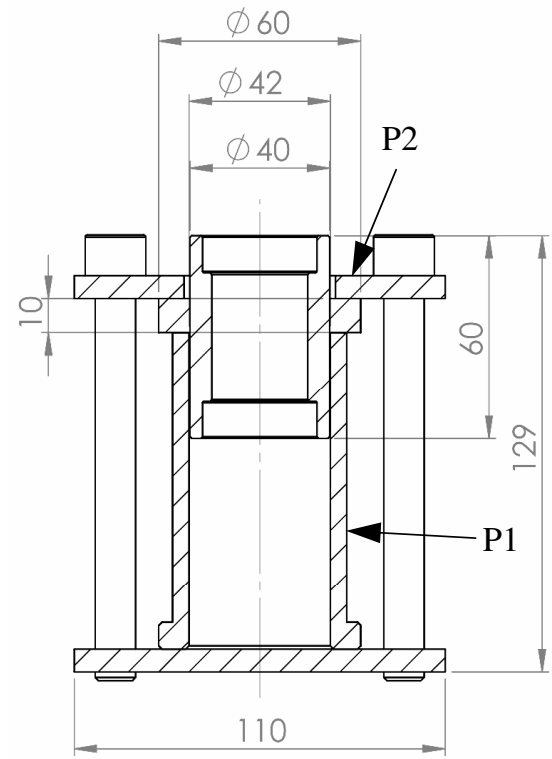

(b)

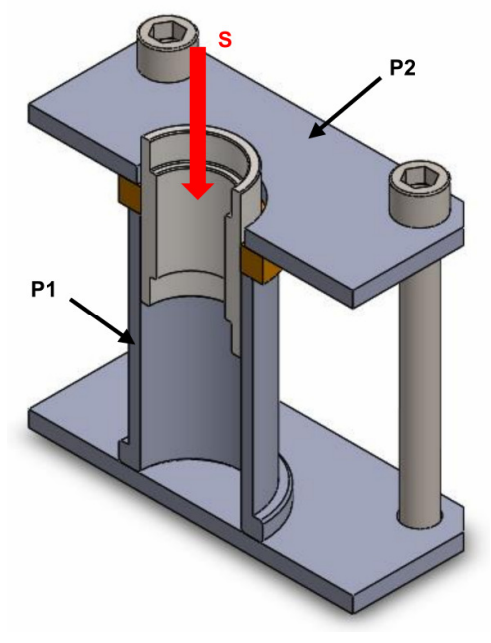

(c)

Figure 2 - Annular specimen: (a)-(b) technical drawing, (c) 3D model

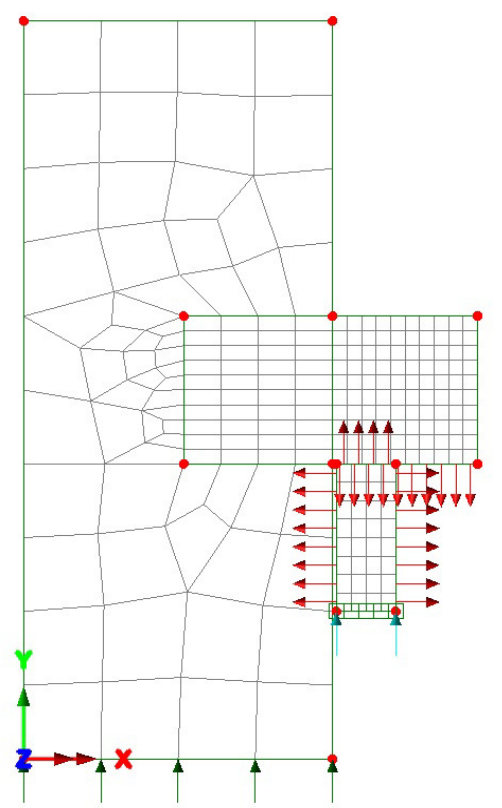

(a) 


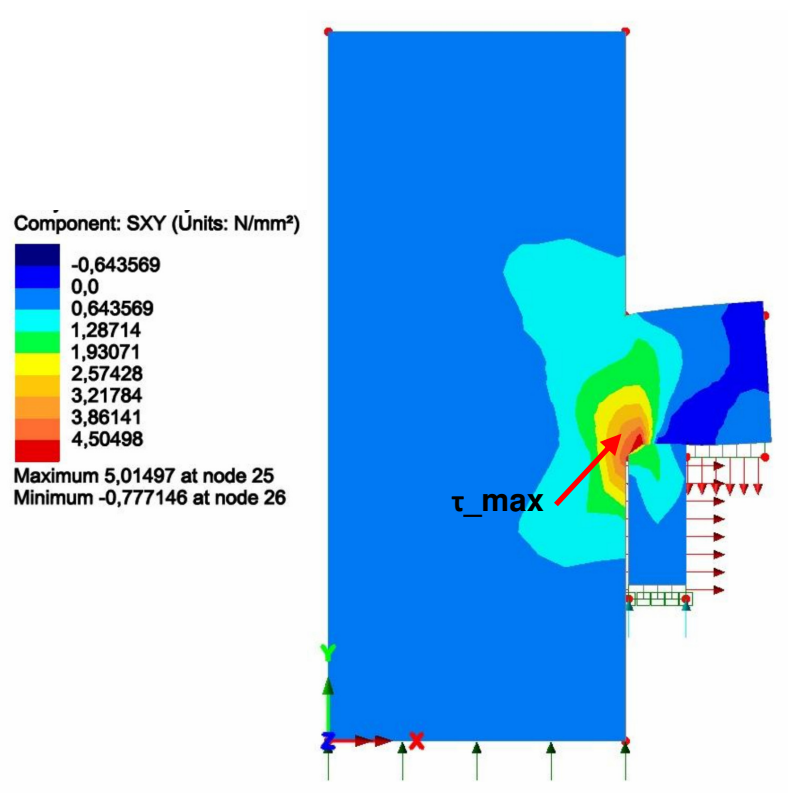

(b)

Figure 3 - Annular specimen: (a) FE model, (b) shear stress distribution

The annular specimen showed an excessive deformation due to the out-of-plane loading thus giving a premature failure, due to the shear and peel stress concentration on the bottom edge.

This confirmed the prediction from the FE analysis. Consequently, we decided to exclude these configurations and focus only the TAST-like specimen (Figure 4) and the torsional specimen (Figure 6).

\subsection{Experimental plan}

Figure $8 \mathrm{a}$ and $\mathrm{b}$ show respectively a TAST-like and a torsional specimen.

Both specimens were made of mild steel and elastic polyurethane and were manufactured through the same procedure, involving three steps. First, we degreased the bonding surfaces of the steel adherends, then sandblasted by angular steel grit. Second, a solventbased adhesive was applied manually. Third, the adherends were placed into a preheated mold and polyurethane casting started after the adherends reached the mold temperature.

The tests have been performed on a Galdabini SUN 500, an electromechanical dynamometer with a maximum axial load of $5 \mathrm{kN}$. The tests were quasi-static, by applying a $1 \mathrm{~mm} / \mathrm{min}$ displacement law, up to complete failure of the joint.

Table 2: Scoring matrix

\begin{tabular}{|l|c|c|c|c|c|}
\cline { 3 - 6 } \multicolumn{2}{c|}{} & \multicolumn{5}{c|}{ Specimen } \\
\cline { 3 - 6 } \multicolumn{1}{c|}{ TAST } & Annular & TAST-like & Torsional \\
\hline \multicolumn{1}{|c|}{ Client needs } & $W$ & \multicolumn{4}{|c|}{ Score } \\
\hline $\begin{array}{l}\text { Simple } \\
\text { manufacturing }\end{array}$ & 5 & 5 & 5 & 3 & 1 \\
\hline $\begin{array}{l}\text { Uniform shear } \\
\text { stress field }\end{array}$ & 5 & 1 & 1 & 4 & 5 \\
\hline Usefulness & 5 & 1 & 1 & 4 & 5 \\
\hline $\begin{array}{l}\text { Applicable to an } \\
\text { axial dynamometer }\end{array}$ & 4 & 5 & 4 & 2 & 2 \\
\hline Low cost & 3 & 3 & 3 & 2 & 2 \\
\hline \multicolumn{2}{|c|}{ Total $\boldsymbol{W} \boldsymbol{x}$ Score $)$} & $\mathbf{6 4}$ & $\mathbf{6 0}$ & $\mathbf{6 9}$ & $\mathbf{6 9}$ \\
\hline
\end{tabular}

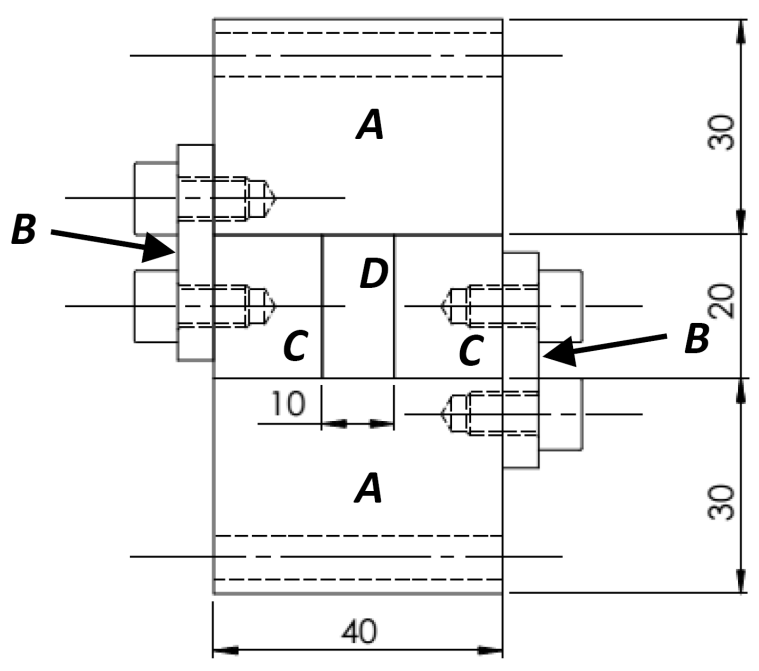

(a)

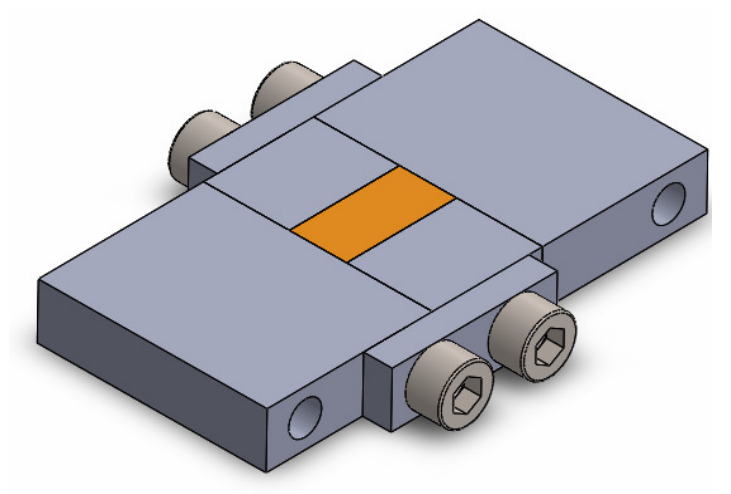

(b)

Figure 4 - TAST-like specimen: (a) technical drawing, (b) 3D model

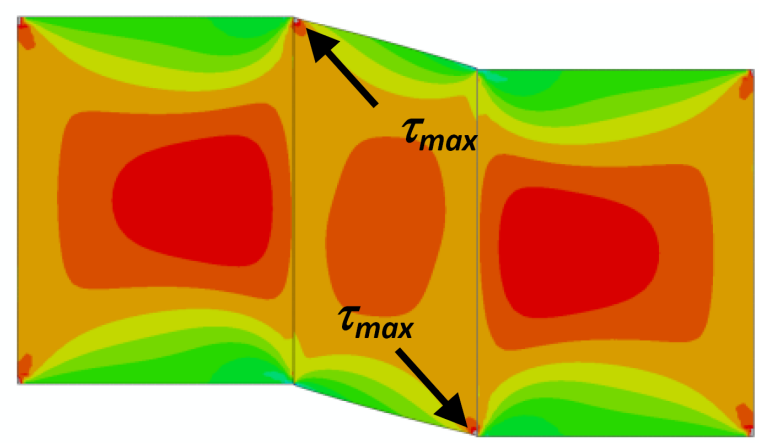

(a)

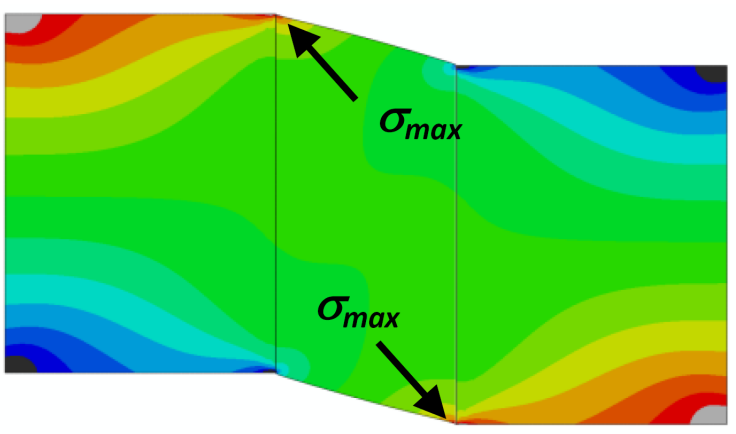

(b)

Figure 5 - TAST-like specimen: (a) shear stress, (b) peel stress 


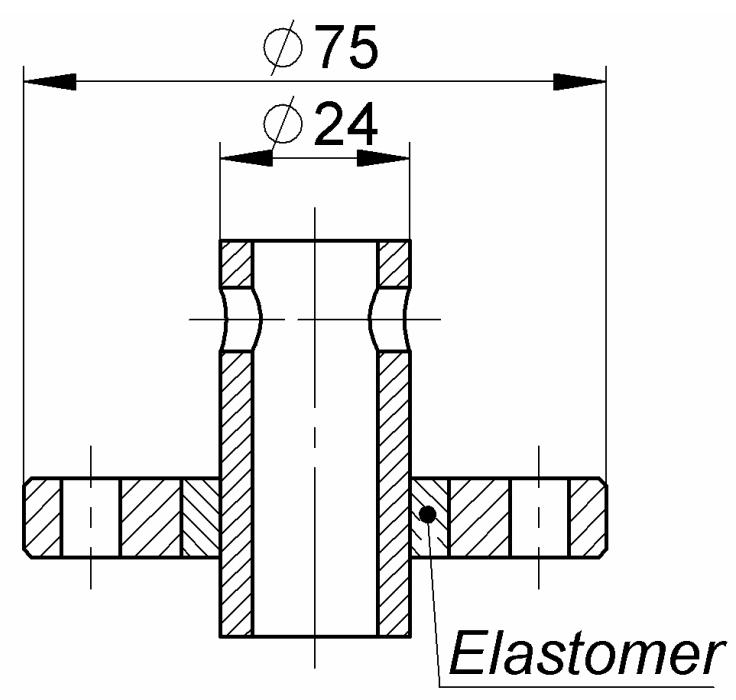

(a)

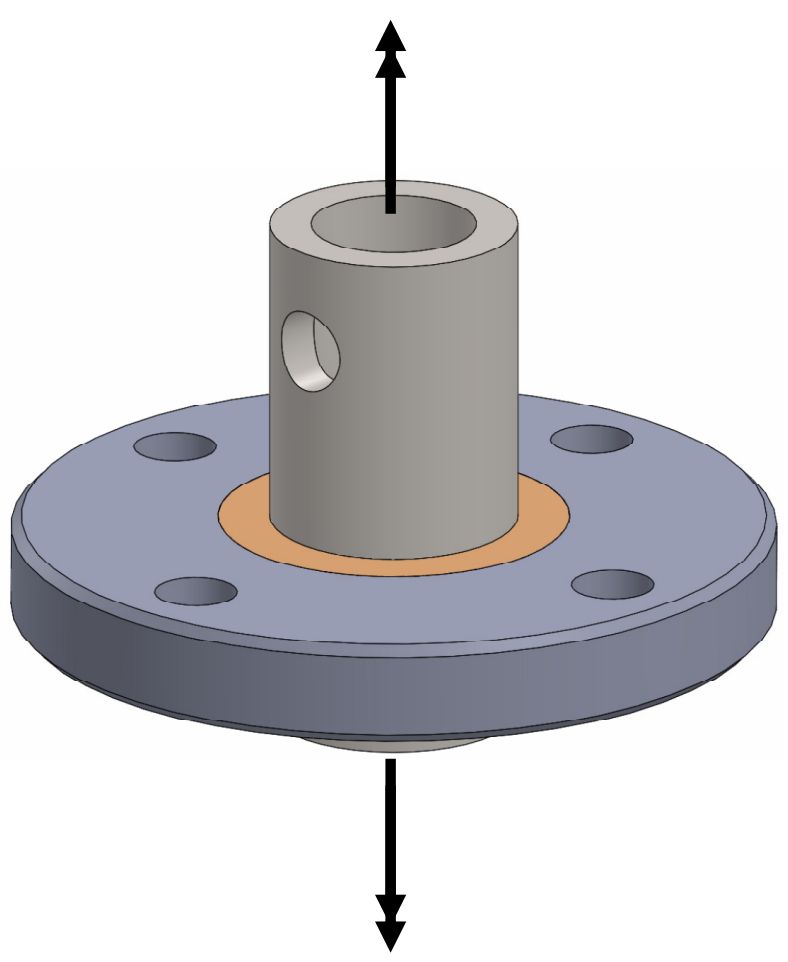

(b)

Figure 6 - Torsional specimen: sketch (a) and 3D model (b)
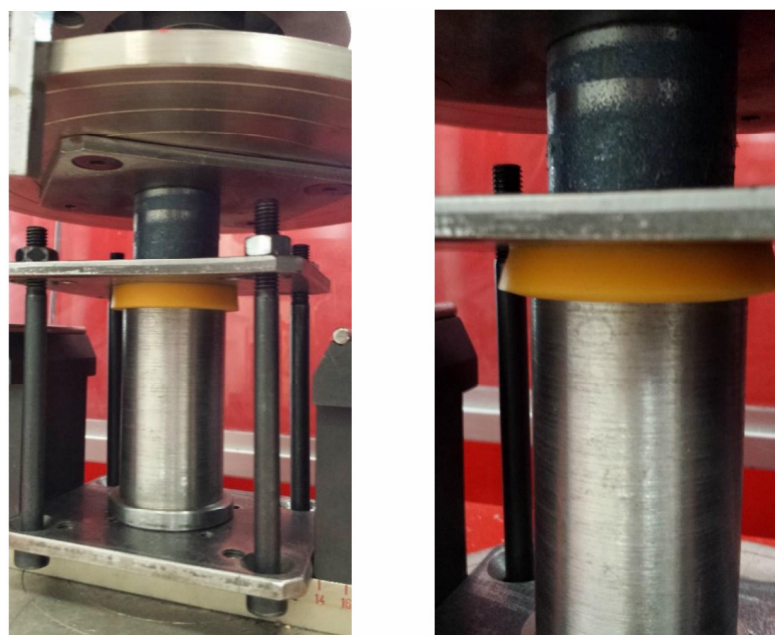

Figure 7 - Test on annular specimen

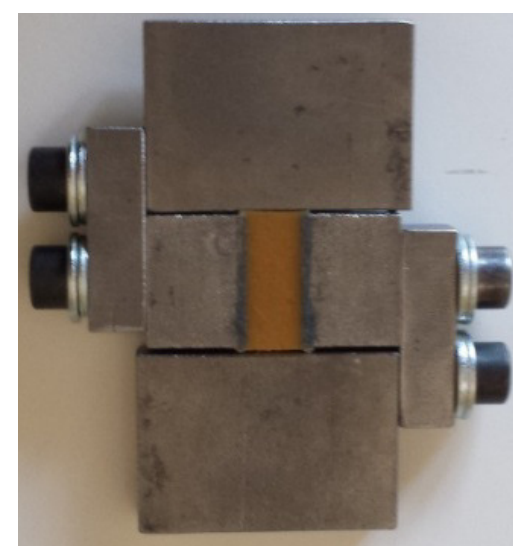

(a)

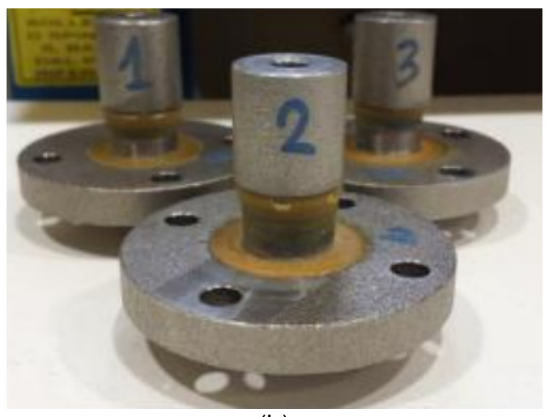

(b)

Figure 8 - Sample of Tast-like (a) and torsional (b) specimen

The experimental tests on the TAST-like specimens (Figure 9a) investigated the applicability of this specimen in assessing the effect of temperature on the joint strength. Three temperature levels were investigated, from room temperature up to the maximum operating temperature. A thermal chamber installed on the dynamometer was used to set the desired temperature. In order to ensure the desired temperature level, the specimens were stored in the thermal chamber for at least 30 minutes before starting the test.

The tests on the torsional specimens (Figure 9b) were performed on the same dynamometer, using the equipment in Figure 10b. These tests were aimed to assess both the specimen and the kinematism used, and were performed at room temperature.Figure 10a describes the schematic of the kinematism used to perform torsional tests on the specimens of Figure $8 \mathrm{~b}$, through the tensile testing machine available in our laboratory. According to the kinematic analysis of the system, the twist angle on the specimen $(\theta=\alpha+\beta)$ can be found as a function of the stroke of the top arm, $\Delta$, and of the dimensions $l$ and $b$, by solving this system of equations:

$$
\left\{\begin{array}{l}
\Delta+b=l \sin \beta+b \cos \alpha+l \sin \alpha \\
l \cos \beta=l \cos \alpha-b \sin \alpha
\end{array}\right.
$$

Figure 10b shows a 3D drawing of the kinematism, which was designed accordingly and made of steel. This equipment is composed by a bottom $(A)$ and top $(B)$ arm, connected, through fork-pin coupling, to the crossheads of the dynamometer. The coupling between the lower arm and the shaft $(C)$ of the specimen is performed through a transverse pin. The flange $(F)$ is fixed to the top arm through a plate (D) and backplate (E), of equal thickness. The whole system was designed 
in order to compensate out of plane bending moments on the specimen, and the bolted connections were chosen in accordance with standard design criteria.

\subsection{Results and discussions}

Figure 9a and $\mathrm{b}$ show, the debonding on a TAST-like specimen and the large strains occurring on a torsional specimen, respectively: the red lines in Figure 9b were radial straight lines at the beginning of the test. For TAST-like specimens, Figure 11a reports the curves of the average shear stress on the adhesive as a function of the stroke. The average shear stress was calculated as the ratio between the tensile load and the area of the bonded surface of the joint.

Figure $11 \mathrm{~b}$ reports the peak values of the average shear stress as a function of the test temperature.

For torsional specimen, Figure 12 describes the shear stress on the adhesive layer as a function of the twist angle $\theta$. This stress was calculated through the following equation:

$$
\tau_{t}=\frac{2 F l \cos \beta}{\pi h d^{2}}
$$

where $F$ is the instantaneous tensile load, $l$ is the length of the top and bottom arm (A and B in Figure 10b), $\beta$ is opening angle of the bottom arm, while $h$ and $d$ are the thickness and the inner diameter of polyurethane ring, respectively.

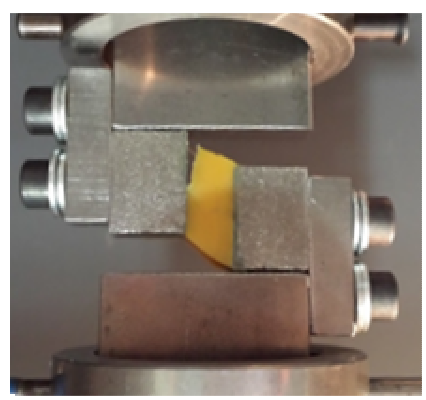

(a)

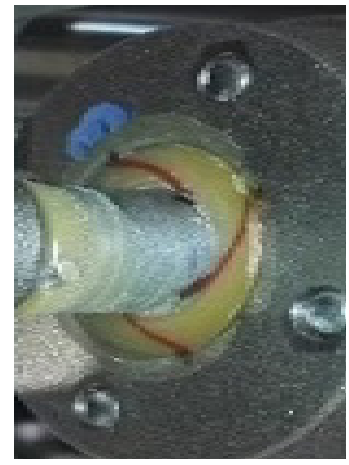

(b)

Figure 9 - Test on a TAST-like (a) and on a torsional (b) specimen.

Both the TAST-like and the torsional specimens show a good replicability between the shear stress curves. The TAST-like specimens (Figure 11a), exhibit a remarkable dispersion of the failure stroke, probably caused by a different failure propagation among the specimens. The initial part of the curves shows a stiffer response followed by a stiffness decrease as failure starts, up to a sudden complete failure of the joint.

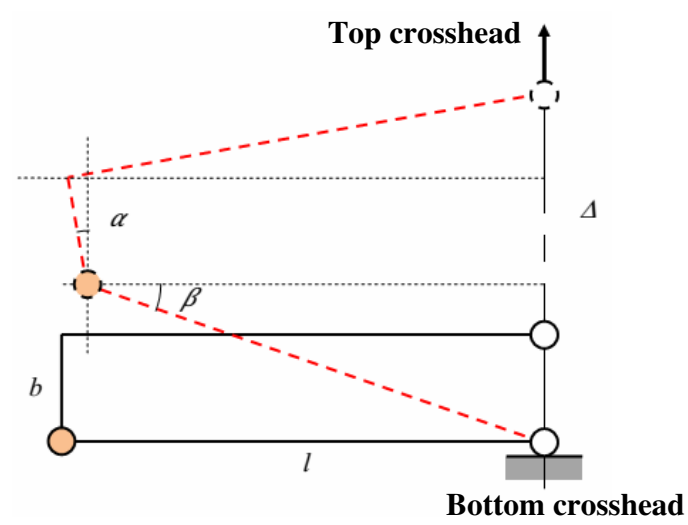

(a)

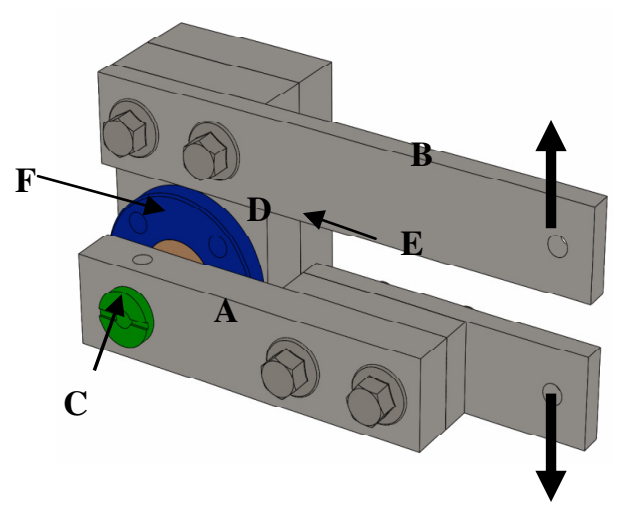

(b)

Figure 10 - Schematic of the traction-torsion kinematism (a) and 3D drawing of the designed system.

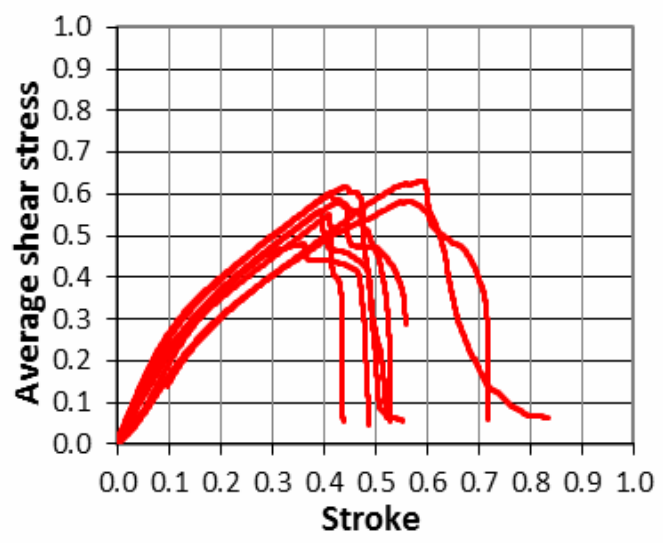

(a)

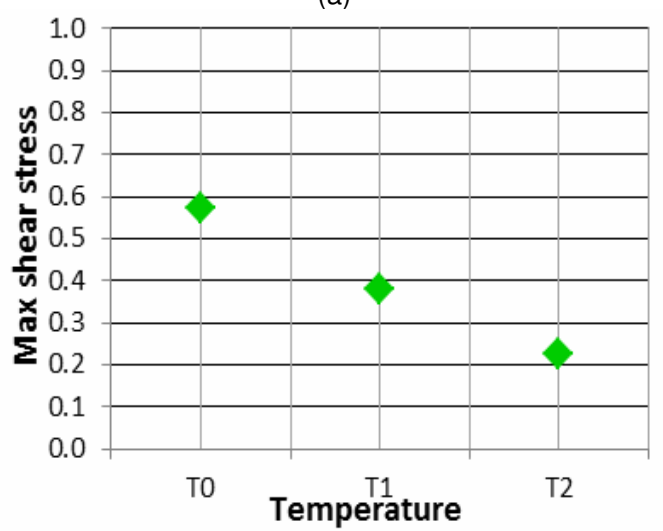

(b)

Figure 11 - Normalized TAST-like test results at room temperature (a) and effect of temperature (b). 
Figure $11 \mathrm{~b}$ highlights a remarkable decrease in the shear strength of the joint, as temperature increases. The curves in Figure 12 show an increasing joint stiffness as the twist angle increases, which can be imputed to the large strains occurring to the polyurethane annular ring. On the whole, the proposed specimens are a simple and efficient technique to assess the joint strength of thin film adhesives whose adherends have a remarkably different stiffness.

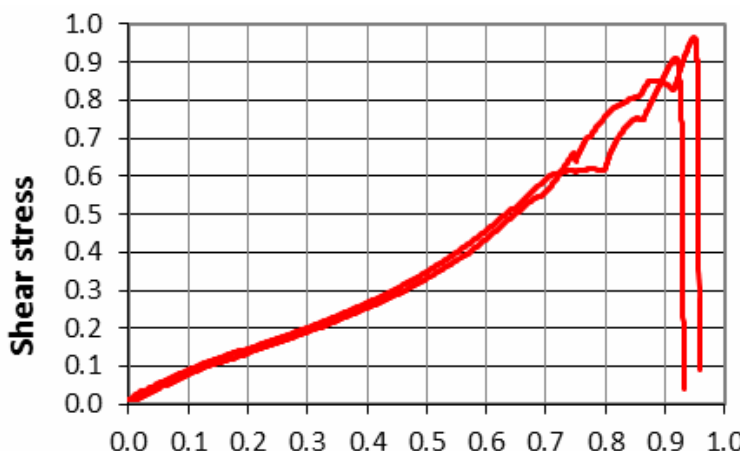

Twist angle

Figure 12 - Normalized torsional test curves

\section{CONCLUSIONS}

The work proposed, designed and experimentally assessed four specimens for the characterization of thin adhesive films between a metallic and an elastomeric adherend.

According to a conceptual design step and some preliminary assessments, two simple and innovative specimens (a tensile and a torsional one) were investigated in detail, An ad-hoc fixture allowed to test the torsional specimen using a dynamometer. The proposed TAST-like and torsional specimens are suitable to characterize bonded joints between adherends with different stiffness. In particular, the TAST-like specimen is more suitable for a qualitative comparison between different bonding conditions. On the other hand, the torsional specimen gives an accurate shear strength evaluation.

\section{REFERENCES}

[1] A. Stevenson, INT. J. Adhes. Adhes., 5(2), (1985)
[2] R. F. Hamade, J. of Adhes. Sci. and Tech., 23 (2009) 579-600

[3] K. M. Liechti et al., Int. J. of Fract. 1989, 39, 217-234

[4] A.B. Othman, Polymer Testing, 8 (1989), 289-299

[5] http://www.testresources.net/applications/standards /astm/astm-d429-rubber-to-metal-adhesion-tests

[6] www.dowautomotive.com, 299-51993-0612BBI

[7] D. Castagnetti, E. Dragoni, A. Spaggiari, J. of Adhes. Sci. and Tech., 24, (2010); 1959-1976.

[8] D. Castagnetti, A. Spaggiari, E. Dragoni, The Journal of Adhesion, 87(7-8) (2011), 1-24.

[9] A. Spaggiari, D. Castagnetti, E. Dragoni, The Journal of Adhesion, 88(4-6) 2012; 499-512.

[10]A. Spaggiari, D. Castagnetti, E. Dragoni, The Journal of Adhesion, 89(8) 2013; 666-675.

[11] ASTM International D 5656 - 04, 100 Barr Harbor Drive, West Conshohocken, PA 19428-2959, United States.

\section{КАРАКТЕРИЗАЦИЈА СМИЦАЈНОГ НАПОНА МЕТАЛНО - ЕЛАСТОМЕРНИХ ЗАЛЕПЉЕНИХ ЗГЛОБОВА}

\section{М. Рагни, Д. Кастањети, А. Спађари, Ф. Мућини, Е. Драгони, М. Милели, С. Гирландо, П. Борги}

Карактеризација смицјаног напона метално еластомерних залепљених зглобова укључујући пријањање са изузетно различитом крутошћу, има посебан интерес за индустријску примену. Овај рад предлаже и испитује три иновативна примерака (осно симетрични прстенасти, затезни и обртни) наменски развијене за контролу различитих пријањања у везама са лепком у танком филму. Дебели адерентни тест узорак између крутих пријањања се користи за процену лепка по самом себи. Рад се фокусира на метално - еластомерне полиуретанске лепљиве спојеве са лепком без растварача. Сви тестови се изводе коришћењем осног динамометра, користес́и наменски развијено ућвршћење за претварање затезног оптерећења у обртни момент за обртни узорак. Затезни и обртни узорци дају најпоузданију карактеризацију смицања. 